\title{
Character Education in Online Learning on Citizenship Education (College Student's Perspective)
}

\author{
Fathikah Fauziah Hanum $^{1 *}$
}

\author{
${ }^{1}$ Universitas Negeri Yogyakarta \\ *fauziahh20@uny.ac.id
}

\begin{abstract}
This study aims to determine college student perspectives on whether Citizenship Education through online learning can strengthen student character. The problems are in online learning according to various student perspectives from previous studies are not satisfactory in terms of understanding the material, student creativity, students become less active. Beside, online learning is only effective for theory and theory and practicum courses, while for practice courses and field study, it is less effective. Whereas education is to shape personality, make students become good characters. Therefore, it is also necessary to evaluate the application of online learning related to Citizenship Education as character education. This study uses a descriptive qualitative research approach. The research subjects were class leaders in five study programs at Universitas Negeri Yogyakarta who had taken online Citizenship Education learning. The results showed that according to students, online learning requires students to learn to understand technology, besides that it can instill values such as religion, discipline, responsibility, honesty, independence and democracy.
\end{abstract}

Keywords: character education, citizenship education, online learning

\section{INTRODUCTION}

Industry 4.0 is nothing less than the fourth industrial revolution: The first three industrial revolutions came about as a result of mechanisation, electricity and IT. Now, the introduction of the Internet of Things and Services into the manufacturing environment is ushering in a fourth industrial revolution. In the future, businesses will establish global networks that incorporate their machinery, warehousing systems and production facilities in the shape of Cyber-Physical Systems (CPS). The terms Internet of Things (IOT) and cyber-physical systems indicate what is at stake here. It is about networking digitally the maximum possible number of elements involved in production process- es, support services, and logistics. In this way, the material melds with the digital. Everything from a local production line to global value chains is to be globally networked and locally regulated, as in the often-cited example of highly customizable products. All manipulable objects in the production process are to be fitted with data transponders that communicate position and production status to the machines doing the processing work [1].

The impact of changes due to the use of digital and internet technology, according to Kasali, does not only occur in changes in industry and the business world, but also in the government and education sectors. Changes in the education sector where the world of education is required to respond to global demands and the digital world. The distracting waves in education include: a) "on demand" educational services and skills, including lecturing exams; b) "Open Source" education and skills services; c) mobile and responsive educational applications; d) a more personal curriculum; e) unlimited content services; f) collaborative education platform, and; f) Free online courses and materials [2]. The educational paradigm requires learning by utilizing this digital technology.

Students' access to new technology has kept them connected. This new technology enables increased distance education possibilities [3]. A constant connectivity available to students was the ability to communicate with fellow classmates and the instructor [4]. This can be a solution to the current corona virus problem. Corona Virus or known as COVID-19 has now spread to various countries in the world. WHO (World Health Organization) has declared COVID-19 a Global Emergency or pandemic on March 11, 2020 [5].

To reduce the risk of transmitting the virus, students, in this case school and college students, are required to spend time at home by studying, discussing, doing assignments, and examinations with media online. The learning innovation impact of COVID-19 actually opens a new paradigm for educational institutions that no longer describes the learning process through face-to-face in the classroom. Online information technology systems play an important role in education that must be prepared to carry out the learning from home method. The learning from home policy requires students and educators to understand the information technology system and apply it in 
improving the quality of education [6]. This improvement in the quality of education based on the goals of education in Indonesia.

According to Indonesian regulations, namely Law No. 20 of 2003 concerning the national education system, education is an effort based on awareness and planning to create a learning process and a learning atmosphere. So that students can actively develop their potential to gain skills, noble character, intelligence, personality, selfcontrol, and religious spiritual strength needed by themselves and society. Therefor according to Kamus Besar Bahasa Indonesia (KBBI), education is the process of changing the attitude and behavior of a person or group of people in an effort to mature humans through teaching and training efforts. Then according to Singh, education policy di abad ke 21 should take the lead to actualize moral education [7].

Thus, every course in higher education must reflect these educational goals, as well as citizenship education. In addition, Citizenship Education is a value education, which means that through Citizenship Education, it is hoped that the values, morals, and norms that are considered good by the nation and the state are for students, so that it supports the efforts of nation and character building [8]. Citizenship Education as value education in the new paradigm must also follow technological developments by implementing online learning.

There are many problems in online learning. According to various student perspectives from previous studies, they are not satisfactory in terms of understanding the material, student creativity, students become less active [6]. Beside, online learning is only effective for theory and theory and practicum courses, while for practice courses and field study, it is less effective [9]. Whereas education is to shape personality, make students become good characters. Therefore, it is also necessary to evaluate the application of online learning related to Citizenship Education as character education.

\section{METHOD}

This study aims to determine college student perspectives on whether Citizenship Education through online learning can strengthen student character. This research is a descriptive study with a qualitative research method approach because the researcher wants to know the respondents' opinions and a more detailed and in-depth understanding of college student perspectives on whether Citizenship Education through online learning can strengthen student character. Determination of research subjects purposively. That is, deliberately choosing research subjects/ informants by researchers based on certain criteria or considerations. The criteria or considerations used in this study are representatives from the class who have a leading role and represent the class. The subjects of this study are class leader majoring in mathematics, chemistry education, civil engineering,
Indonesian education and the arts of crafts. Data obtained through interviews and documentation. The validity of the data with a crosscheck interview results between research subjects with documentation. Inductive analysis is used assess and analyze data.

\section{RESULT AND DISCUSSION}

Character education is a national movement creating schools that foster ethical, responsible and caring young people by modelling and teaching good character through emphasis on universal values that we all share. It is the intentional, proactive effort by schools, districts and states to instil in their students important core ethical values such as caring, honesty, fairness, responsibility and respect for self and others [10]. Character education aims to develop a person's ability to make good and bad decisions, maintain what is good and realize that goodness in everyday life wholeheartedly [11]. Thomas Lickona describes character education as the deliberate effort to cultivate virtue.

Character education includes a broad range of concepts such as positive school culture, moral education, just communities, caring school communities, socialemotional learning, positive youth development, civic education, and service learning [10]. Thus, through civic education (citizenship education), character values can be instilled in students.

One of the course that carry the mission of building good citizen character is Citizenship Education (Civics). Citizenship education or civics education has a mission to shape students so that later they become citizens of society as well as citizens who are smart, skilled and have a character as a guarantee for the sustainability of the nation and state [12]. According to Branson Citizenship education in facing the globalization era should develop civic competences. Among these civic competences covering knowledge citizenship (civic knowledge), civic skills, and civic disposition. The main objective of the civic disposition is to cultivate the character of citizens, both private characters such as; moral responsibility, selfdiscipline, and respect for the human dignity of each individual, as well as public character, for example; concern as a citizen, politeness, heeding the rules of the game (rule of law), critical thinking, and a willingness to listen, negotiate and compromise[13].

Character education can be applied in online learning if it applies several models of collaboration, coaching, presenting and reflecting [14]. The results of the study showed, the perspectives of students at Yogyakarta State University, the cultivation of character values can be obtained through online learning in the Citizenship Education course. 
The results of student perspectives on character values that can be obtained through online education are as follows:

\section{Discipline}

Discipline is an action that shows orderly behavior and is obedient to various rules and regulations [11]. According to the student the discipline can be obtained through: a) start and end classes on time, and build a conducive online classroom atmosphere; b) time management discipline; c) Get used to learning on time

\section{Responsibility}

Responsibility is the attitude and behavior of a person to carry out his duties and obligations, which he should do, towards himself, society, the environment (natural, social and cultural), the country and God Almighty [11]. According to the student the responsibility can be instil through: a) Distribution of tasks in online learning, presentations; b) Comply with the rules and agreements that have been made for the online learning process; c) students can take responsibility for the learning itself, such as how students can do their jobs without direct supervision.

what happens during the online learning process is the relationship between teacher and students and the content and process changes in an important way, namely: "learners become more active in their responsibility for learning," and instructors act as "facilitators, strategists, and coordinators [15].

\section{Religious}

Religion is the attitude and behavior that is obedient in carrying out the teachings of the religion it adheres to, is tolerant of the practice of other religions, and lives in harmony with adherents of other religions [11]. According to the student the religious can be action by pray before and after online learning

\section{Democratic}

Ways of thinking, behaving and acting that value the rights and obligations of oneself and others [11]. The students say that democracy value in online learning on citizenship education can be form: a) appreciate opinions during discussions in online forums; b) express opinions well; c) elearning also requires active participation from students; d) Deliberations are held to decide what media is suitable so that all students can access it. An attitude of tolerance and consideration also supports the proceedings of the deliberations.

\section{Independence}

Independence is an attitude and behavior that does not depend on others and uses all energy, thoughts, time to realize hopes, dreams and ideals [11]. The students say that independence value in online learning on citizenship education can be form: a) students are required to understand the material more deeply independently. although they can still ask the teacher; b) They able to increase the independence of students in finding learning material sources; c) Through online learning where supervision is not as tight as when learning face-to-face, of course it will go a long way to train our independence. One of them is when we look for information that we don't understand. When learning face-to-face, we will rely on teachers / lecturers to answer our questions

\section{Honesty}

Honest is behavior that is carried out in an effort to make himself a person who can always be trusted in his words, actions and work [11]. The students say that honesty value in online learning on citizenship education can be form being honest with the presence that was done and being honest about the constraints of other things.

\section{Creative}

Creative is thinking and doing something to produce a new way or result from something that is already owned [11]. Educators can encourage students to express new ideas in online discussions. Whether the ideas are correct or incorrect, other students might engage with them, to confirm or correct them. Thus, students might benefit from such exchanges [16]. There are advantages where mobile devices assist in students learning (online learning). These advantages are (a) accessing information quickly, (b) communication and collaboration of content, (c) various ways of learning, and (d) learning situations such as the able to collect data and interact with content as they immediately came across it in their daily lives. The students were creating a virtual history blog and shared that the experience was meaningful because they were able to post content immediately to the blog wherever they were during the day [4].

Same with the result of the study the student say that the creativity of students in utilizing technology properly and correctly, this of course adds to the understanding and knowledge of students about the use of technology in learning.

Thus, the online learnig system can instill good values in students. Especially in the midst of the Covid-19 pandemic, online learning is the right solution. The Covid19 pandemic could trigger a change from textual learning to contextual / online learning. With this system, students can get to know this 21 st century technology. Online 
learning requires students to learn to understand technology and have good character.

\section{CONCLUSION}

Character education in online learning also requires students or students to be more active, disciplined, and independent in finding their own material (self-study) through the references used. Learning with the e-learning system can still instill good values in students. However, in practice, both lecturers and students must try harder by instilling self-awareness and self-discipline to carry out the online learning process. They can wove together to create increased levels of student self-responsibility [17]. Lecturers can provide rules or regulations accompanied by consequences so that these values can instill at students and make the good character on them.

\section{ACKNOWLEDGMENT}

I would like to thank my students for our lengthy conversations and for their valuable input on this article. Moreover, the study was supported by Universitas Negeri Yogyakarta.

\section{REFERENCES}

[1] S. Pfeiffer, "The Vision of 'Industrie 4.0' in the Making - a Case of Future Told, Tamed, and Traded," Nanoethics, vol. 11, no. 1 , pp. 107-121, 2017, doi: 10.1007/s11569-016-0280-3.

[2] R. Kasali, DISTRUBTION. PT Gramedia Pustaka Utama, 2017.

[3] K. R. Vareberg, Z. Luo, D. Westerman, M. Bartels, and P. Lindmark, "For a Good Class, Email: Technologically-Mediated out-of-Class Communication and Instructional Outcomes," Internet High. Educ., vol. 47, p. 100761, 2020, doi: 10.1016/j.iheduc.2020.100761.

[4] J. Gikas and M. M. Grant, "Mobile computing devices in higher education: Student perspectives on learning with cellphones, smartphones \& social media," Internet High. Educ., vol. 19, pp. 18-26, 2013, doi: 10.1016/j.iheduc.2013.06.002.

[5] R. Djalante et al., "Review and Analysis of current responses to COVID-19 in Indonesia: Period of January to March
2020," Prog. Disaster Sci., vol. 6, p. 100091, 2020, doi: 10.1016/j.pdisas.2020.100091.

[6] Rahmawati and E. M. Putri, "Learning From Home dalam Perspektif Persepsi Mahasiswa Era Pandemi Covid-19," in Seminar Nasional Hardiknas, 2020, pp. 17-24.

[7] B. Singh, "Character Education in the 21st Century," J. Soc. Stud., vol. 15, no. 1, pp. 1-8, 2019, doi: 10.21831/jss.v15i1.25226.

[8] B. Maftuh, "Internalisasi Nilai-Nilai Pancasila dan Nasionalisme Melalui Pendidikan Kewarganegaraan," Educationist, vol. II, no. 2, 2008.

[9] Hikmat, E. Hermawan, Aldim, and Irwandi, "Efektivitas Pembalajaran Daring Selama Masa Pandemi Covid-19: Sebuah Survey Online," Digit. Libr. UIN SUnan Gung Djati, Bandung, pp. 1-7, 2020.

[10] A. Pala, "the Need for Character Education," Int. J. Soc. Sci. Humanit. Stud., vol. 3, no. 2, pp. 23-32, 2011.

[11] K. Komalasari and D. Saripudin, Pendidikan Karakter. Bandung: Reflika Aditama, 2017.

[12] B. Mulyono, "Reorientasi Civic Disposition dalam Kurikulum Pendidikan Kewarganegaraan Sebagai Upaya Membentuk Warga Negara yang Ideal," $J$. Civ. Media Kaji. Kewarganegaraan, vol. 14, no. 2, pp. 218-225, 2017, doi: 10.21831/civics.v14i2.17007.

[13] M. S. (Eds) Branson, Belajar civic education dari Amerika (Terjemahan Syarifudin, dkk). Yogyakarta: Lembaga Kajian Islam dan Sosial (LKIS) dan The Asia Foundation (TAF), 1999.

[14] M. Mustofa, R. Ahmadi, and I. W. Karimullah, "Islamic Character Education in E-Learning Model: How Should It be Implemented?," J. Sains Sosio Hum., vol. 4, no. 1, pp. 89-93, 2020.

[15] S. Bailey, S. Hendricks, and S. Applewhite, "Student Perspectives of Assessment 
Strategies in Online Courses," J. Interact.

Online Learn., vol. 13, no. 3, pp. 112-125, 2015.

[16] G. Chen, C. K. Lo, and L. Hu, "Sustaining online academic discussions: Identifying the characteristics of messages that receive responses," Comput. Educ., vol. 156, no. October 2019, p. 103938, 2020, doi: 10.1016/j.compedu.2020.103938.

[17] W. Barber and S. King, "Teacher-student perspectives of invisible pedagogy: New directions in online problem-based learning environments," Electron. J. e-Learning, vol. 14, no. 4, pp. 235-243, 2016. 